Tf I lived to be over one hundred years old, they would not let me go.

According to the Fifth Amendment to the U.S. Constitution, every person accused of a crime has the right to be represented by an attorney. If the accused cannot afford an attorney, one will be provided by the state. The Constitution does not, however, address the competency of that attorney. I honestly believe that most public defenders ranked lower in their class than their opponents, the assistant district attorneys. And since they get paid a salary, there is no incentive for them to walk the extra mile trying to win their cases. Their caseload means they do not have the time, the resources, or often the motivation to do all they can for the people they represent. Why would they? They get paid the same for a case that lasts half a day as for a case that lasts eight months.

I clearly remember the first time I spoke to the public defender in the county jail. I was called to a bright, cold interview room, inside of which were two chairs separated by a table. As soon as I got inside the room, the jail guard instructed me through an intercom speaker to sit down and wait for my attorney. The interview was supposed to be privileged communication, but hearing the guard's voice coming from the speaker on the wall made me doubt the privacy of the conversation I would have with the public defender, since the guard could hear everything I said with a simple push of a button.

As I waited nervously in that cold room, I tried to remember any details from my case that could be helpful for my defence. After a few minutes of waiting, the P.D. showed up and in a tone colder than the room, he introduced himself. Then, without giving me an opportunity to say anything, he proceeded to tell me his plan: "I spent a lot of time reading your file, a lot of time during the weekend, about two hours. And I think you should take a deal: fifteen-to-life".

As soon as I heard that, I knew I had no chance of winning my case. I had no doubt I would go to prison. The only question now was for how long. At that time, my English was not good enough to communicate what I had in mind. My vocabulary was very limited, especially with legal terminology. Even worse, I had no idea of the new laws that were recently passed, such as Proposition 8, better known as the Three-Strikes law, which not only gave repeat offenders life in prison, but also gave consecutive sentences to others. Making it effectively a One-Strike law. Surprised that he just wanted me to accept a fifteen-to-life sentence without asking me a single question, 
I foolishly asked if he wanted to hear my side of the story? He looked at me as if I were an idiot. How dare I insult his professional expertise! He took a deep breath, as if he were counting to ten before answering so he would not explode in rage because of my audacity in challenging his plan. Then, he said, "I told you, I read the charges and the police report, and I think you should take the deal"'.

In my erroneous belief that he was there to defend me. I spoke once again: "But - everything you read is what they say I did. They are against me. You don't want to know my side of the story?" He rolled his eyes, as if telling me that my side of the story did not matter. There was nothing else I could say. He was there to do the necessary paperwork to expedite my entry into prison. He was not interested in wasting his time listening to my whining. He had a lot more cases to deal with. Then he told me to think about the deal and that he would contact me in a few days to get my decision. "You'll probably do only twelve years and nine months of that sentence". After that, he got up and left the room. Somehow the room felt warmer after he left.

For some days, I thought about taking the deal, then things began to go downhill fast. The public defender, or public pretender, as they are also known, called me and told me the deal had changed to add six more years. Two weeks later he called me again and told me the deal had changed once again to add 16 years to the original offer of fifteen, for a total of 31-to-life.

"Who was killed? Who was tortured? Who almost died?", I thought, trying to make logical sense of the changing plea offer. The frightening part was the counterfactual premise that in this country, the accused is innocent until proven guilty, contradicted by the ease with which a defendant is convicted and sentenced to prison or death - unless of course, the accused is rich or, especially, if he or she is rich and famous.

Faced with the possibility of going to trial, I asked the P.D. how many other prisoners he was assigned to represent. He told me, "Not too many at this time. About 60".

"What about the Assistant D.A.?", I asked. "How many cases does he have?"

The P.D. said, "Yours, and a murder case".

I quickly realized that my only chance of not losing everything would be to tell the truth. I told the P.D. I wanted to go to trial and tell everything that happened, the way it happened. The jury would get to hear my side of 
the story and decide accordingly. There was no physical evidence with the exception of a phone tap that appeared damaging, but I could explain what was said and could prove it with the right translation. Any other thing that appeared strange was explainable if only I had been asked. But no one ever asked me. Along with legal representation, the Constitution provides for a criminal trial for every defendant who chooses not to plead guilty. My P.D. had no choice but to take my case to trial, even as he continued to try to convince me to plead guilty.

Before my trial, I told the P.D. that the phone recording the police were using against me was not properly transcribed. But he insisted it was. I know it was not because some things spoken in Spanish were written as "unintelligible". Had they used a bilingual transcriber they would have heard the reason why I said what I said. But they only transcribed what was said in English.

Later, I told him to go interview a couple of witnesses who could clarify or support what I was saying. He said he could not do that because they were "friends" of the victim. I may be extremely naive when it comes to the law, but I doubt that it is illegal to knock on a door and ask a person if they would like to describe what they witnessed. The P.D. did not call anyone to testify in my behalf. No one. At the trial, everyone who took the stand testified against me. Witnesses who disagreed with the prosecutor's witnesses were never called.

Obviously during the trial, everything looked terrible. Sometimes I thought the Assistant D.A. was speaking about a monster from the movies. Then I remembered he was talking about me. The witnesses lied and exaggerated many things and strategically "forgot" to mention anything that would explain key factors in the case, which could have helped me. I knew it would be very hard to be on the stand trying to defend myself, but I knew I had to do it. The prosecution witnesses said terrible things about me. I hoped my P.D. would make the time to prepare me to tell my side of the story on the stand. But at the end, he told me I would not get on the stand.

"What do you mean?", I nearly screamed. "You heard what they said. I need to defend myself!"

"No, no", he kept insisting. "There's no evidence. Plus, I don't want to put you on the stand to face a very experienced Assistant District Attorney".

Before the jurors left to make their decision, the judge instructed them that each testimony of the witnesses could be taken as evidence, and that 
would be enough to find me guilty. It would therefore be impossible for them to come back with anything but a guilty verdict.

I looked at the P.D. and said, "You knew this and you didn't let me defend myself? I need to testify!"

His only response was, "It's too late now". Having me testify would take another two days of his busy schedule. He just wanted to get my case over with.

At the end, it would have been better for me to take twice the original deal they offered me. I practically got a worse sentence than a life without parole, which means I will not go before the parole board until I have served thirty-two years behind bars. I believe society would be surprised to know how many prisoners get sentenced to death in prison, that is, sentenced to a number of years that keep them locked up until they die, even when they have not killed anyone, with so little evidence and without the proper representation. My P.D. never asked me to tell him exactly what happened. He never heard my side of the story. He did not need to. He had read it from the police report.

\section{ABOUT THE AUTHOR}

Victor Becerra is incarcerated in California. He can be contacted at:

Victor Becerra, K09324

CTF-Central

P.O. Box 689

Soledad, California 93960-0689

USA 